\title{
Osiedle im. Jana Zamoyskiego \\ w Zamościu - realizacja założeń \\ programu rządowego "PR-5” \\ i późniejsze działania modernizacyjne
}

\author{
Michał Dmitruk \\ Wydziat Budownictwa i Architektury, Katedra Architektury, \\ Urbanistyki i Planowania Przestrzennego, Politechnika Lubelska \\ Faculty of Civil Engineering and Architecture, Department of Architecture, \\ Urban and Spatial Planning, Lublin University of Technology
}

\begin{abstract}
Streszczenie: Pośród wielu osiedli mieszkalnych z elementów prefabrykowanych, realizowanych w Polsce na przestrzeni lat 70-tych do 90-tych XX wieku osiedle im. Jana Zamoyskiego w Zamościu zasługuje na szczególną uwagę. Tworzone w ramach Programu Rządowego PR-5 osiedle charakteryzuje się wyjątkowymi walorami urbanistyczno-architektonicznymi i awangardowymi rozwiązaniami technicznymi, niespotykanymi w żadnym z wcześniej zrealizowanych osiedli wielkopłytowych na terenie Polski. Obecnie administracja osiedla dokłada wszelkich starań w celu modernizacji, rewitalizacji i utrzymania standardów użytkowych budynków.
\end{abstract}

Słowa kluczowe: wielka płyta, prefabrykacja, modernizacja, rewitalizacja, humanizacja

\section{Wprowadzenie}

Miasto Zamość znane jest przede wszystkim ze swojej historycznej części, zwanej „Starym Miastem”, zbudowanej według planu opracowanego przez wybitnego włoskiego architekta Bernarda Morando ${ }^{1}$ i wpisanej w 1992 na Listę Światowego Dziedzictwa Kultury UNESCO. Rynek otoczony renesansowymi, XVI i XVII wiecznymi kamienicami, a także barokowy ratusz z 52 metrową wieżą ${ }^{2}$ rysującą się wyraźnie w panoramie miasta stanowią o tożsamości miejsca i kojarzone są nierozerwalnie z Zamościem. W tak wyśmienitym pod względem architektonicznym i urbanistycznym sąsiedztwie, obiekty współczesne, mniej spektakularne i znaczące, choć również cenne, mogą pozostać niezauważone. Przykładem takiej architektury jest osiedle im. Jana Zamoyskiego, położone zaledwie 800 metrów na wschód od "Starego Miasta", realizowane od wczesnych lat 80-tych po lata 90-te XX wieku.

Obszar ten już od roku 1939 wskazywany był jako naturalny i optymalny kierunek rozwoju miasta Zamość w planie zagospodarowania przestrzennego, opracowanym przez urbanistów Jana Zachwatowicza i Władysława Wieczorkiewicza, poprzedzonym studium z 1936 roku $^{3}$. Plansza ilustrująca opracowanie planistyczne, zatytułowana: "Szkicowy projekt planu zabudowania" określała lokalizację "Nowej Osady" na terenach obecnie istniejącego osiedla, ze względu na korzystne warunki fizjograficzne, jak i możliwość kształtowania nowej zabudowy w układzie linearnym, z główną osią prowadzącą w kierunku Starego Miasta ${ }^{4}$. Głównym zadaniem

3 Żygawski J., 2015. Niezrealizowane projekty śródmieścia Zamościa w XIX i XX wieku na podstawie archiwalnych opracowań kartograficznych i planistycznych, TEKA Komisji Urbanistyki i Architektury PAN oddział w Krakowie, tom XLIII, Kraków. 
projektowanej koloni, miało być odciążenie funkcjonalne i komunikacyjne części historycznej Zamościa - miała więc ona charakter podrzędny i uzupełniający. Planowana była zabudowa niska, o niewielkiej intensywności, w celu utworzenia licznych terenów zielonych. Oprócz funkcji mieszkalnej, planowano również stworzenie obiektów edukacyjnych i kulturowych. Realizację planu zabudowy tego obszaru przerwał na wiele lat wybuch II Wojny Światowej.

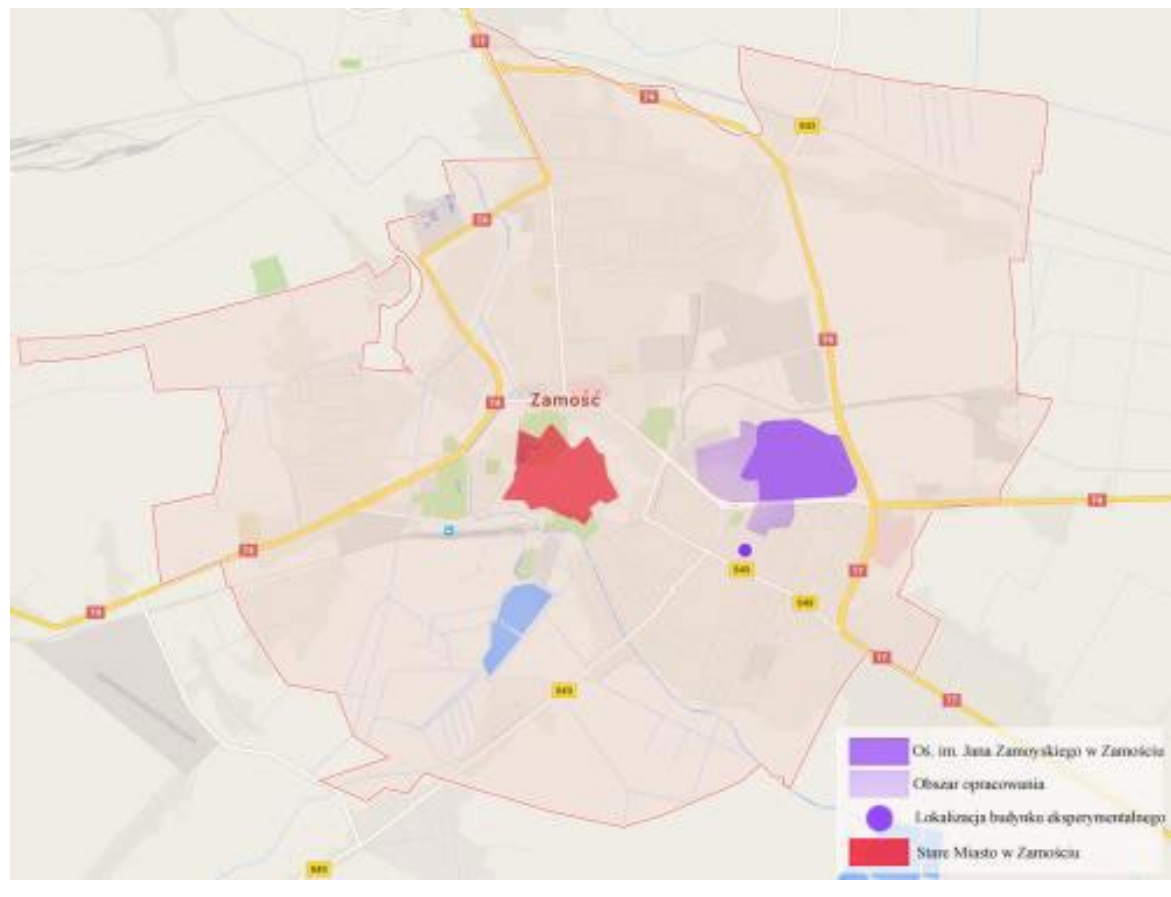

Ryc. 1. Lokalizacja omawianego obszaru osiedla w relacji do Starego Miasta w Zamościu. Autor grafiki: Michał Dmitruk na bazie mapy Google

The location of the discussed area in relation to the Old Town in Zamość Author graphics: Michał Dmitruk - based on Google maps

\section{Geneza powstania osiedla im. Jana Zamoyskiego w Zamościu}

Osiedle w jego obecnej formie nie było pierwszym i jedynym założeniem, planowanym we wspomnianej lokalizacji. Tereny te pierwotnie miały zostać przeznaczone na stworzenie nowoczesnego ośrodka usługowo-mieszkalnego, stanowiącego nowe centrum Zamościa. Już w latach 60-tych XX wieku przygotowano dwie koncepcje zagospodarowania przestrzeni wzdłuż ulicy Lwowskiej. Pierwsza z nich, zaprojektowana przez Lubelską pracownię "Miastoprojekt" pod kierownictwem mgr. inż. Jana Adamczyka, oprócz średniowysokiej zabudowy mieszkalnej zakładała lokalizację usług wyższego rzędu, takich jak szpitale i centra administracyjno-biurowe. Projektowana dzielnica miała w założeniu operować jako uzupełnienie do funkcji kulturalno-turystycznej, zlokalizowanej całkowicie w obrębie Starego Miasta. Komunikację terenu oparto o istniejącą siatkę drogową, rozbudowaną o nowoczesną linię kolejową ${ }^{5}$. Drugim przedstawionym opracowaniem, autorstwa Biura Projektów Budownictwa Ogólnego w Krakowie, pod kierownictwem inż. arch. Mieczysława Turskiego był projekt noszący nazwę "Nowe Miasto". Przedstawiono nowoczesne rozwiązanie urbanistyczne, oparte na wyraźnej osi kompozycyjnej, wypełnionej w dużej mierze zielenią i ukierunkowanej na staromiejską część Zamościa. W założeniu planistycznym zakładano lokalizację funkcji administracyjno-usługowych, mieszkalnych a także przemysłowych (zakłady chemiczne) $^{6}$. W tym celu zaproponowano rozbudowę sieci komunikacji kołowej - jako pasmo obwodowe, okalające osadę i kolejowej, poprzez zlokalizowanie podziemnego dworca autobusowo-pociągowego. 
W centralnym punkcie osiedla, na styku z osią kompozycyjną zlokalizowano wysokie budynki mieszkalne, jako punkt określający wizualnie centrum założenia. Plan realizacji podzielony został na etapy, z planowaną datą ukończenia prac przypadającą na rok 2001.
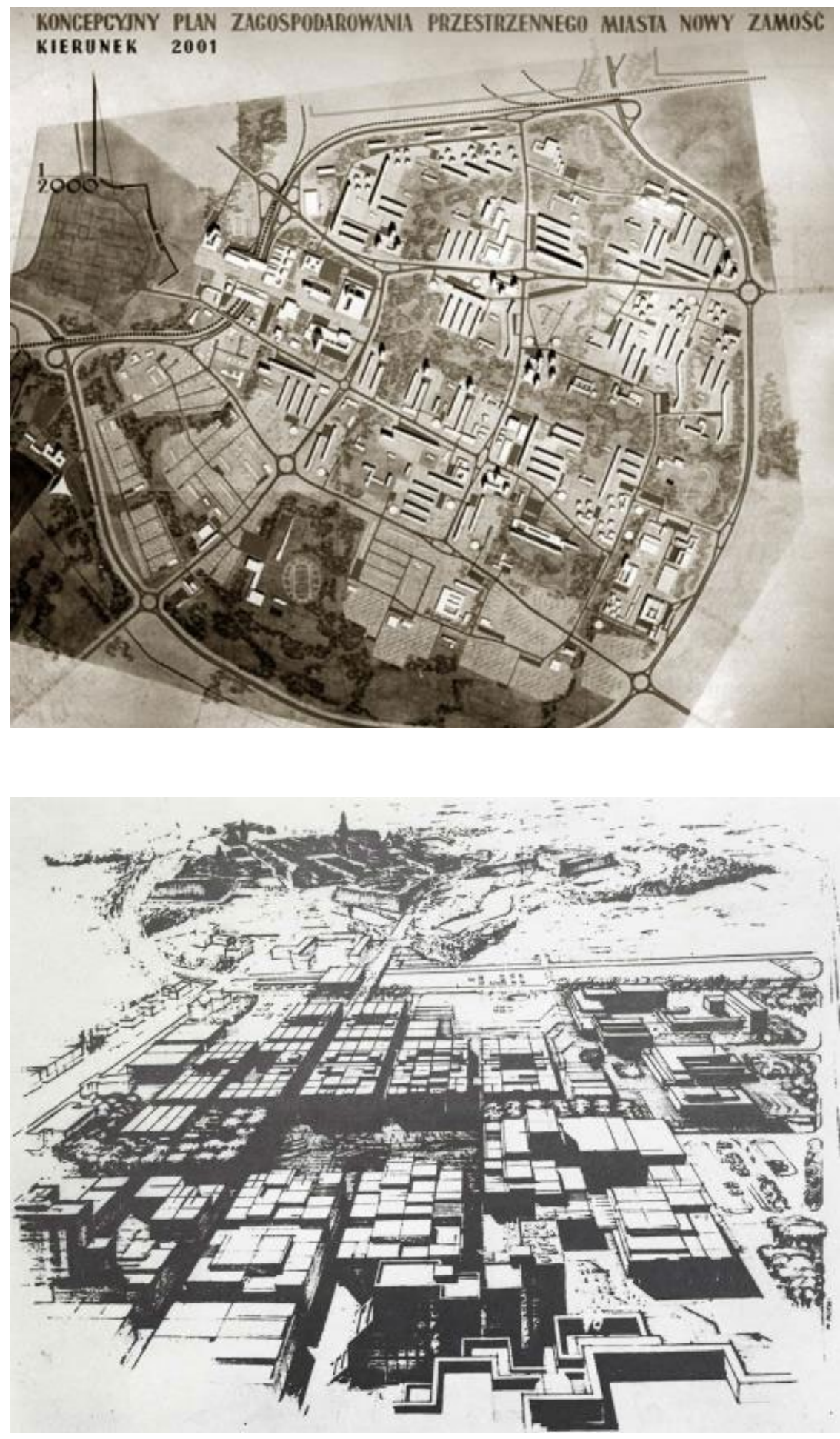

Ryc. 2. Plan dzielnicy "Nowe Miasto" autorstwa Biura Projektów Budownictwa Ogólnego w Krakowie. Źródło: Biuro Planowania Przestrzennego w Zamościu, spis zdawczo-odbiorczy nr 1

"New City" district plan. Author: Biura Projektów Budownictwa Ogólnego w Krakowie Source: Spatial Planning Office of Zamość - archives.

Ryc. 3. Widok dzielnicy „Centrum Usług Wielkomiejskich" na tle Starego Miasta. Autor: Jacek M. Jedynak. Źródło: Biuro Planowania Przestrzennego w Zamościu

View of "Metropolital Public Utility Centre" district on the background of the Old Town. Author: Jacek M. Jedynak Source: Spatial Planning Office of Zamość - archives. 
W roku 1969 zmieniono jednak koncepcję rozwoju miasta Zamościa i ogłoszono konkurs na Projekt Nowego Centrum Zamościa na terenach ujętych we wcześniejszych opracowaniach, będącego miejscem obsługi kultury, szkolnictwa i handlu. W roku 1970, prezydium Miejskiej Rady Narodowej zdecydowało o przyznaniu I nagrody za projekt "Centrum Usług Wielkomiejskich", opracowany przez pracownię "Warcent" pod kierunkiem architekta Jacka Jedynaka. Projekt zakładał utworzenie kwartałowej zabudowy, nawiązującej w swojej formie i skali do staromiejskiej, szachownicowej zabudowy Zamościa. Na wzór zamojskiego rynku, uformowano po środku dzielnicy plac, stanowiący centralny punkt kompozycyjny i funkcjonalny na którym krzyżowały się główne arterie komunikacyjne, jak i skupiały się wyspecjalizowane usługi miejskie. Architekturę budynków uformowano wg reguł modernistycznych, na zasadzie addycji lub subtrakcji sześciennych brył do prostopadłościennych form podstawowych. Utworzenie drugiego, wyraźnego centrum Zamościa miało za zadanie utrwalić podział funkcji turystyczno-kulturowej Starego Miasta i funkcji administracyjnej i handlowo-gastronomicznej nowej dzielnicy, zapewniającej obsługę całego regionu. Realizację założenia projektowego rozpoczęto poprzez wytyczenie obiektów i miejscowe rozpoczęcie prac ziemnych, jednak ze względu na przypadający na lata 1970-1980 kryzys gospodarczy, a także wolniejszy niż zakładany rozwój miasta, zrezygnowano z realizacji na rzecz bardziej pożądanego w ówczesnym czasie osiedla mieszkaniowego.

Konieczność budowy nowej jednostki mieszkaniowej na terenie Zamościa związany był ściśle z reformą podziału administracyjnego kraju z roku $1975^{7}$, nadającą mu status miasta wojewódzkiego. Potrzeby i aspiracje nowej stolicy regionu zakładały znaczny wzrost ilości mieszkańców z 41000 do 70000 do roku 1990, a także konieczność zrealizowania do tego czasu 15000 mieszkań ${ }^{8}$.

Rada Ministrów PRL, Uchwałą Nr 266/72 zainicjowała powstanie rządowego programu badawczo-rozwojowego kraju, którego podpunkt nr 5 brzmiał: „Kompleksowy rozwój budownictwa mieszkaniowego” 9 i zawierał wytyczne lokalizacyjne czterech przewidzianych eksperymentalnych zespołów zabudowy miejskiej, z których zrealizowane zostało jedynie Zamojskie założenie. Pozostałe trzy osiedla: „Chełmońskiego" w Krakowie, "Stella” w Tychach i „Białołęka Dworska” w Warszawie nie zostały ostatecznie zrealizowane w związku z gwałtownym załamaniem się gospodarki w latach 1979-1990.

Zadaniem nakreślonym przez Program Rządowy 5 (PR-5) było stworzenie warunków dla budowy w Zamościu 7300 tys. mieszkań na przestrzeni lat 1971-1990. Osiedle nazwano roboczo "Nowym Miastem II”. W ramach programu PR-5 przewidziano dla Zamościa budowę sześciu kolonii osadniczych z zabudową wielorodzinną i usługową, realizowanych kolejno następującymi po sobie etapami.

Realizacja programu początkowo szła pomyślnie, ze względu na sprzyjającą sytuację ekonomiczną w kraju. W ramach prac badawczych opracowano nowe rozwiązania i technologie inżynieryjne i materiałowe, których zadaniem było zwiększenie efektywności technicznej, optymalizacja kosztów budowy przy jednoczesnej poprawie walorów estetycznych i funkcjonalnych architektury wykonanej z wielkowymiarowych elementów prefabrykowanych.

Do realizacji tego ambitnego przedsięwzięcia urbanistyczno-architektoniczno-technicznego zatrudniono wielobranżowy zespół specjalistów, który kompleksowo i wielopłaszczyznowo podszedł do zaprojektowania, a następnie do realizacji osiedla. Generalnym projektantem całego założenia był inżynier architekt Bohdan Jan Jezierski.

Kolejno w skład zespołu ekspertów wchodzili:

- Grażyna Konarska, Jacek Zieliński, Jolanta Gołębiewska, Irmina Samełko-Benedek,

- Jan Szumański, Zdzisław Życieński i Maria Sieńko - architektura i urbanistyka,

- Jerzy Zbyszyński - konstrukcja,

- Henryk Brzeski - instalacje sanitarne,

- Antoni Ginalski - instalacje elektryczne,

- Euzebiusz Maj - zieleń,

7 Dz. U. z 1975 r. Nr 16, poz. 91. Po reformie administracyjnej, z dnia 1 stycznia 1999, Zamość utracił status miasta wojewódzkiego. Ustanowiono 16 nowych województw w celu utworzenia większych regionów, które mogłyby konkurować z innymi regionami po wstąpieniu Polski do Unii Europejskiej.

8 Gliński A. [red.], 1983. Architektura. Czasopismo Stowarzyszenia Architektów Polskich, Arkady, Warszawa.

9 Zieleniewski S., Nowak Z.,1975. Tło i charakterystyka ogólna programu rzadowego PR-5 „Kompleksowy rozwój budownictwa mieszkaniowego”, Akademia Ekonomiczna. Instytut Organizacji, Zarządzania i Ekonomiki Przemysłu Budowlanego. Zakład Ekonomiki Budownictwa i Inwestycji, Kraków. 
Władysław Sobolewski - komunikacja,

- Zdzisław Biernacki - fizjografia i ochrona środowiska,

- Maria Stawicka-Wałkowska - zagadnienia akustyczne.

Kierownictwo nad budową zespołu objął Kombinat Budowlany w Zamościu, w osobach: inż. R. Władyga, inż. E. Typiak i mgr inż. G. Sobka.

Zadanie budowy modelowej jednostki mieszkaniowej, mimo późniejszych problemów ekonomicznych centralnie sterowanej gospodarki PRL, udało się zrealizować w całości. W ramach 6 zespołów mieszkaniowych wybudowano 51 wielorodzinnych budynków mieszkalnych o sumarycznej liczbie mieszkań wynoszącej 1727 sztuk, o sumarycznej powierzchni użytkowej 108871 metrów kwadratowych. Każdy zespół posiadał również własny budynek świetlicy, służącej mieszkańcom osiedla (obecnie biblioteka i przedszkola). Wykonano także 3 pawilony handlowo-usługowe o powierzchni całkowitej 2830 metrów kwadratowych, zespoły garaży wbudowanych w skarpy i budynek techniczny do obsługi instalacji elektrycznej i sanitarnej osiedla ${ }^{10}$. W ramach programu PR-5 wybudowano również dwie szkoły ogólnokształcące (SO-1 i SO-2) i dwa przedszkola (jedno obecnie funkcjonuje jako Państwowa Wyższa Szkoła Zawodowa - Instytut Przyrodniczo-Techniczny)

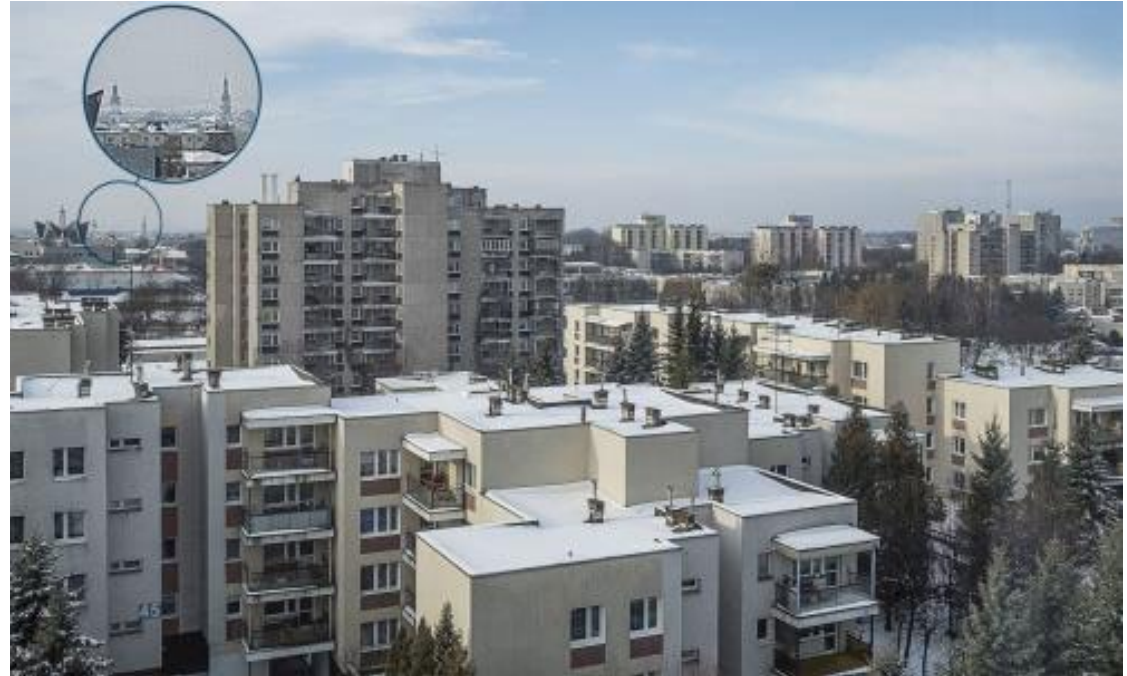

Ryc. 4. Widok na osiedle od strony wschodniej. Na górze z lewej widoczne budynki historycznej części Zamościa. Autor fotografii: Filip Springer Eastern view of the Jan Zamoyski's District. On the upper-left, buildings of the historical part of Zamość can be seen. Author of the photography: Filip Springer

\section{Rozwiązania projektowe a relacja do historycznej architektury Zamościa}

Sąsiedztwo tak znaczącej architektonicznie i historycznie przestrzeni, jaką jest stare miasto w Zamościu zobowiązuje projektanta nowoczesnych osiedli do zachowania szacunku dla istniejącej tkanki miejskiej, a w szczególności gdy projektuje się architekturę o tak pospolitym wyrazie estetycznym, z jakim kojarzone są budynki wielkopłytowe. Główny architekt, Bohdan Jan Jezierski świadomy ciężaru decyzji projektowych, jakie musi podjąć na podstawie szeregu analiz in situ, sformułował listę założeń wyjściowych do projektowania osiedla. Ustalono, iż wszelkie decyzje planistyczne i architektoniczne projektowanego osiedla muszą być podporządkowane rozwiązaniom przestrzennym zespołu staromiejskiego. W związku z powyższym, przeprowadzono analizę punktów widokowych na sylwetę starego miasta i ustalono, iż Nowe Miasto II nie może z tych punktów być widoczne powyżej, bądź pomiędzy liniami zieleni wysokiej, co z kolei pomogło określić maksymalną wysokość i lokalizację budynków na osiedlu. Kolejnym założeniem wyjściowym, a jednocześnie ukłonem w stronę organizacji historycznej tkanki miejskiej, było kształtowanie zespołów mieszkalnych w sposób tworzący wnętrza urbanistyczne nawiązujące do zamojskiego rynku głównego, gdzie otwarta przestrzeń, o formie zbliżonej do 
kwadratu otoczona była ścianami budynków, a trakty komunikacyjne zaprojektowane w układzie szachownicowym przebiegały przez środek powstałego placu ${ }^{11}$.

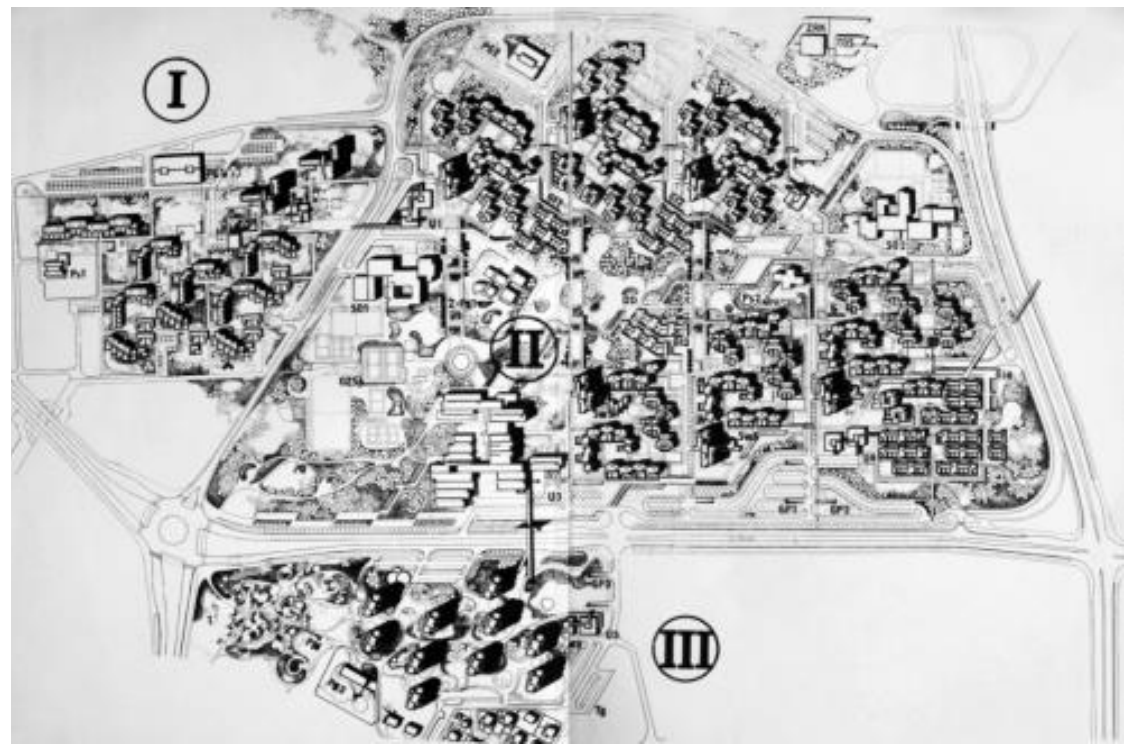

Ryc. 5. Plan Osiedla Nowe Miasto II. Źródło: Architektura. Czasopismo Stowarzyszenia Architektów Polskich.

"New City II"- district plan. Source: Architektura. Czasopismo Stowarzyszenia Architektów Polskich.

Podobnie, jak na staromiejskim rynku ograniczono ruch samochodowy, tak i w projektowanym osiedlu Jana Zamoyskiego wyprowadzono całkowicie auta z przestrzeni międzyblokowej. Nie oznacza to jednak, że pominięto potrzebę posiadania przez mieszkańców własnego pojazdu - co więcej, przewidziany współczynnik miejsc postojowych był o 100\% większy niż ówcześnie obowiązująca norma (1 miejsce na 2 mieszkania) ${ }^{12}$ i zakładał jedno auto na jeden lokal mieszkalny. Miejsca parkingowe dla aut na osiedlu rozwiązano na dwa sposoby:

1. Zlokalizowanie placów postojowych na otwartym powietrzu jedynie po zewnętrznej stronie osiedli, dostępnych z okalającej zespół arterii komunikacyjnej.

2. Zaprojektowanie zespołów garaży wbudowanych w skarpy, w formie „satelit”, połączonych z główną ulicą poprzez prowadzone w zagłębieniach drogi dojazdowe, nad którymi prowadzone były kładki, przez co ruch pieszych nie był zakłócony, a estetyka osiedla nie była zaburzona gęsto zaparkowanymi autami. (Ryc. 6.)

Rozwiązanie opisane w punkcie drugim, choć niezwykle kosztowne i pracochłonne, rozwikłało problem nadmiernej ilości aut w poszczególnych koloniach, z którym to wiele osiedli z elementów prefabrykowanych (a także i budowanych współcześnie) boryka się do dziś. Wnętrza międzyblokowe bez parkujących tam samochodów uzyskały kameralny nastrój. Całe osiedle przecina szeroki pas chodnika, funkcjonującego jako ciąg pieszo-jezdny, tworzący oś oddzielającą część północną od południowej, jednocześnie służąc jako trakt spacerowy i ciąg komunikacyjny dla służb miejskich i ratunkowych. Trasą można przejechać, jednak nie wolno zostawiać na niej auta.

Jednym z założeń wyjściowych osiedla była "humanizacja przestrzennego wyrazu zabudowy"13, sprowadzając architekturę do skali człowieka, tworząc nastrój kameralny i dostosowany do zróżnicowanych potrzeb mieszkańców. Architektura miała tworzyć tożsamość miejsca, poprzez zróżnicowane pod względem wielkości i wyglądu budynki. W każdym realizowanym zespole do budynków wielorodzinnych doprojektowano po trzy jednorodzinne domy szeregowe w celu dywersyfikacji typów budynków mieszkalnych, jak i utrwalenie w architekturze nurtu odejścia od wolnostojącej zabudowy jednorodzinnej.

Poza założeniami przestrzennymi, architekci prowadzili na szeroką skalę studia proporcji elewacji nowoprojektowanych budynków, w nawiązaniu do budynków historycznych Zamościa. Analizowano prawidłowości

11 Gliński A. [red.], 1983. Architektura. Czasopismo Stowarzyszenia Architektów Polskich, Arkady, Warszawa

12 Na podstawie informacji uzyskanych od Spółdzielni Mieszkaniowej im. Jana Zamoyskiego w Zamościu ul. Wyszyńskiego 50 B, 22-400 Zamość.

13 Gliński A. [red.], 1983. Architektura. Czasopismo Stowarzyszenia Architektów Polskich, Arkady, Warszawa 
i rytmy fasady zarówno ratusza, jak i kamienic otaczających rynek w Zamościu i starano analogicznie kształtować bryły obiektów na osiedlu im. Jana Zamoyskiego. Studia zabytkowej zabudowy Zamościa polegały na określeniu odpowiedniej dla założenia projektowego skali i proporcji budynków. Zaobserwowano i przyjęto następujące zależności: $M$ - moduł podstawowy (wysokość kondygnacji mieszkalnej); m - moduł uzupełniający; $\mathrm{p}$ - pas międzyokienny ( $p=M-m)$; $M^{\prime}$ - wysokość kondygnacji przyziemia; $\mathrm{H}$ - wysokość kamienicy dwupiętrowej; $\mathrm{H}$ - wysokość kamienicy piętrowej. Prace analityczne ilustruje rycina $\mathrm{nr} 7$.
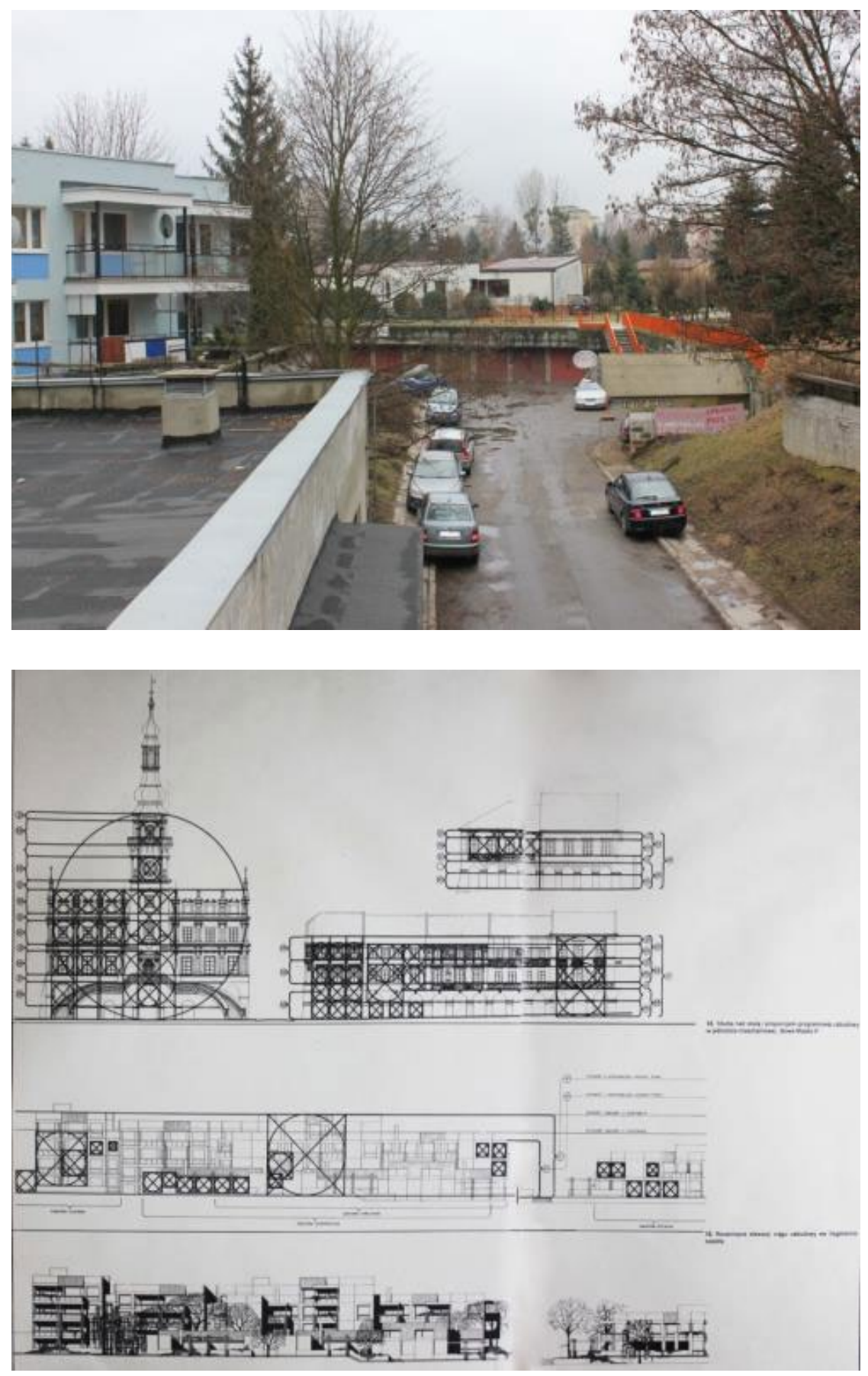

Ryc. 6. Wbudowane w skarpę garaże. Widok z kładki nad drogą dojazdową. Autor fotografii: Michał Dmitruk

Built-in garages. The view from the footbridge over the access road. Author of the photography: Michał Dmitruk

Ryc. 7. Studia nad skala i proporcjami zabytkowej zabudowy Zamościa i projektowanej architektury. Źródło: Architektura. Czasopismo Stowarzyszenia Architektów Polskich.

Studies on the scale and proportions of the old city buildings from Zamość and designed multifamily housing. Source: Architektura. Czasopismo Stowarzyszenia Architektów Polskich. 


\section{Eksperymentalne rozwiązania techniczne, przestrzenne, estetyczne i funkcjonalne}

Budynki na osiedlu Nowe Miasto II realizowane były w technologii wielkopłytowej systemu Kesting ${ }^{14}$, opracowanego na terenie Niemiec Zachodnich. Nowa technologia została zakupiona, a następnie zmodernizowana w zamojskich zakładach prefabrykacji, zwanych „Fabryką domów”. System WK-70 zmodyfikowano w sposób pozwalający na łączenie technologii wielkopłytowej z elementami konstrukcji słupowo - ryglowej, co zapewniało otwarty plan wewnątrz mieszkań oferujący dowolność organizacji ścian działowych. Elementy stropowe również łączono w kierunku poprzecznym, co niwelowało, bądź minimalizowało zjawisko klawiszowania płyt, typowe m.in. dla Płyty Żerańskiej. System po modyfikacjach oznaczono symbolem WKZ-70, gdzie dodatek "Z" oznaczał "zmodyfikowany" (choć wśród lokalnej społeczności inżynierów budowlanych „Z" oznaczało - „zamojski"). Zmodyfikowany system WK-70 umożliwiał również formowanie architektury budynków w sposób niestandardowy dla typowych obiektów wielkopłytowych i umożliwiający kształtowanie dużo swobodniejszej formy architektonicznej, niż kojarzone z technologiami prefabrykacji proste, prostopadłościenne (często uznawane za monotonne) obiekty. Widoczne jest to zarówno w rzucie budynków (zdjęcie lotnicze - Ryc. 8.), jak i obserwując tektonikę elewacji, rozmaitość wykuszy, loggii, balkonów, zagłębień, przesunięć i różnic poziomów.
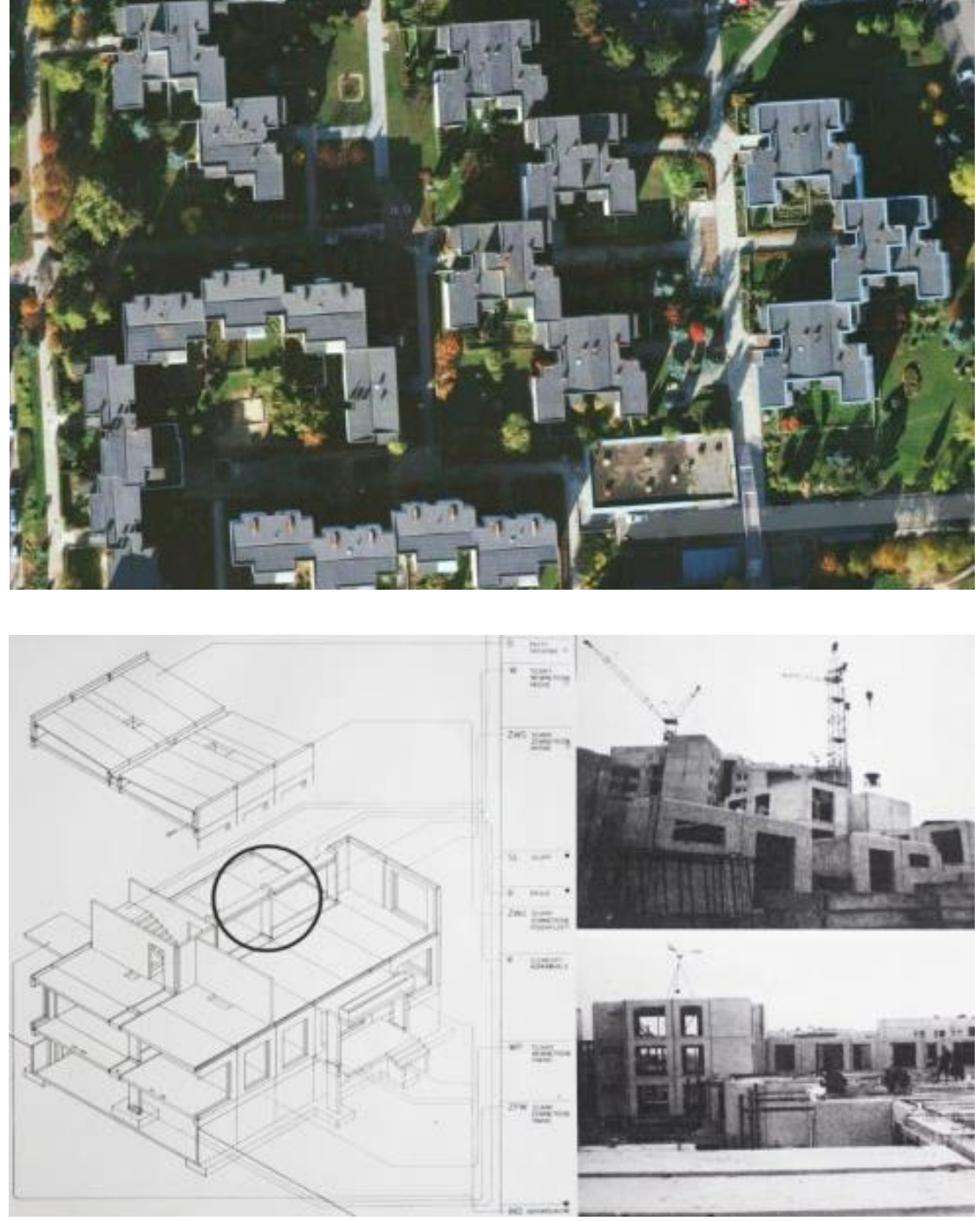

Ryc. 8. Widok lotniczy na fragment osiedla. Źródło: Mapy Google.

Air view on the part of the district. Source: Google maps.

Ryc. 9. Po lewej - schemat konstrukcyjny budynku, po prawej - zdjęcia z budowy osiedla. Źródło: Architektura. Czasopismo Stowarzyszenia Architektów Polskich.

On the left - construction scheme, on the right - photographies from the building site. Source: Architektura. Czasopismo Stowarzyszenia Architektów Polskich. 
Zapotrzebowanie na prefabrykowane elementy konstrukcyjne, zarówno w samym Zamościu, jak i w okolicznych miastach było tak duże, że Zamojska Fabryka Domów w najintensywniejszym okresie pracowała na 3 zmiany, produkując płyty nieprzerwanie 24 godziny na dobę ${ }^{15}$. Zamojskie zakłady dostarczały elementy wielkopłytowe również dla takich miast jak Biłgoraj, Hrubieszów, Tomaszów Lubelski i inne. Fabrykę zamknięto wkrótce po ukończeniu założenia PR-5.

Wprowadzenie do budownictwa nowej technologii, zawsze wymaga zapewnienia wykwalifikowanej kadry robotniczej, aby poprawnie wykonać roboty budowlane. W celu przeszkolenia pracowników w sposobie konstruowania budynków w systemie WKZ-70, postanowiono realizować pierwszy, eksperymentalny budynek przy ulicy Marii Konopnickiej 6 w Zamościu - w pewnym oddaleniu od planowanego osiedla. Prace budowlane prowadzono dwa lata, od listopada 1979 roku do listopada 1981 roku. Budynek eksperymentalny potwierdził poprawność i wykonalność rozwiązań konstrukcyjnych. Czterokondygnacyjny obiekt, oprócz mieszkań, posiadał również komórki lokatorskie, jak i dwie świetlice, zlokalizowane w przyziemiu od strony patio. Bezpośrednio po zakończeniu prac przy ul. Konopnickiej, rozpoczęto realizacje programu PR-5. Budynek Eksperymentalny, po renowacji i termomodernizacji spełnia swoją funkcję do dziś. (Ryc.10.)

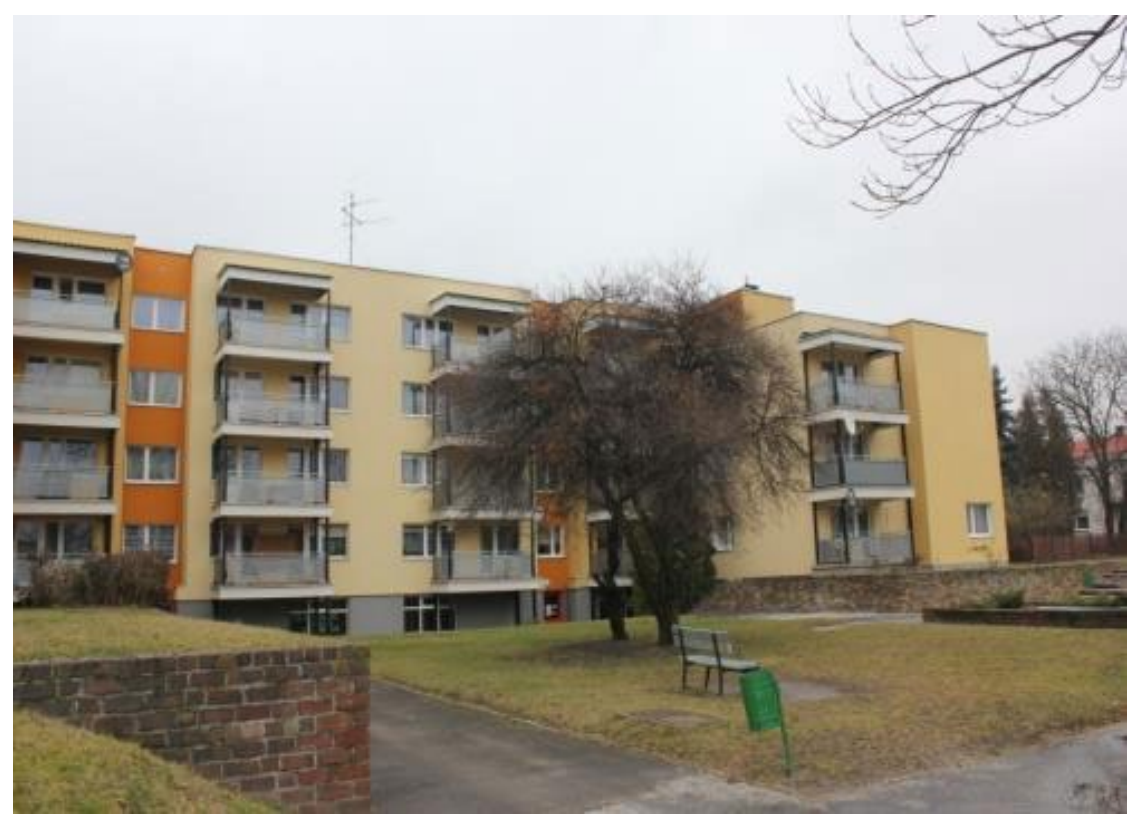

Ryc. 10. Wbudowane Budynek eksperymentalny wykonany w technologii WKZ-70. Autor fotografii: Michał Dmitruk Experimental building, built in WKZ-70 construction system. Author of the photography: Michał Dmitruk

Budynki wznoszone w ramach programu rządowego PR-5 należały do grup niskich (dwu i czterokondygnacyjne) i średniowysokich (ośmiopiętrowe). Budynki niskie formowane były w zespoły o skomplikowanym kształcie, tworzące wewnętrzne dziedzińce, budynki wysokie natomiast były stosunkowo nieliczne i tworzyły dominanty krajobrazowe w każdej z kolonii. Osiedle realizowane było według założonego planu, podzielonego na 6 kolejnych etapów - każdy z nich nazywany był zadaniem I, II, III itd. Każdy zakończony etap tworzył kompletny zespół, z przynależną mu szkołą, świetlicą, budynkiem handlowo - usługowym, wiatami na odpady i zespołami garaży. Architektura obiektów posiadała znacznie wyższy standard funkcjonalny, przestrzenny i estetyczny niż realizowane wcześniej na terenie Polski osiedla wielkopłytowe. Po raz pierwszy przyjęto regułę przy projektowaniu i przydziale mieszkań, że pokój dzienny nie pełni funkcji sypialnej, tylko odrębną rekreacyjną, przez co standardowe $\mathrm{M} 3$ było o około $10 \mathrm{~m}^{2}$ większe niż oferowane wcześniej. Mieszkania były wykonywane w standardzie „pod klucz", co oznacza pełne wykończenie, wraz z umeblowaniem. Posadzka w mieszkaniach była wykonana z drewnianej mozaiki, a każdy przyszły lokator, przed pracami wykończeniowymi lokalu mógł przyjść i na ścianach wewnątrz odnotować, jaki kolor malowania sobie życzy - co było dalekie od zwyczajów panujących w czasach PRL. Na osiedlu zróżnicowany jest również typ budynków mieszkalnych, od wysokich punktowców, poprzez budynki galeriowe, klatkowe, jak i szeregowe, dwupoziomowe domy jednorodzinne, dołączone do 
ciągu budynków czterokondygnacyjnych. Niespotykanym rozwiązaniem były również zaprojektowane przydomowe ogródki prywatne, przynależne do poszczególnych mieszkań na najniższej kondygnacji - rozwiązanie projektowe rozpowszechnione na skalę kraju dopiero w latach współczesnych.

Estetyka przyjęta w projekcie elewacji zakładała rozczłonkowanie i podział brył, w celu stworzenia kameralnej, nieprzytłoczonej ciężką bryłą budynku przestrzeni półpublicznej, dodatkowo liczne przejścia, podcienia, prześwity i place miały spowodować efekt przenikania się strefy zewnętrznej z wewnętrzną. Jednocześnie mnogość loggii i balkonów o układach poprzecznych i podłużnych dodawała budynkom lekkości. Mimo powyższych zabiegów, utrzymano czytelny i jasny podział na strefy wejściowe strefy półpubliczne, półprywatne i strefy zieleni. Projektowane przez Bohdana Jana Jezierskiego place spotkań i place zabaw wykonane z klinkieru niestety nie przetrwały próby czasu i zostały wymienione na ścieżki z kostki brukowej.

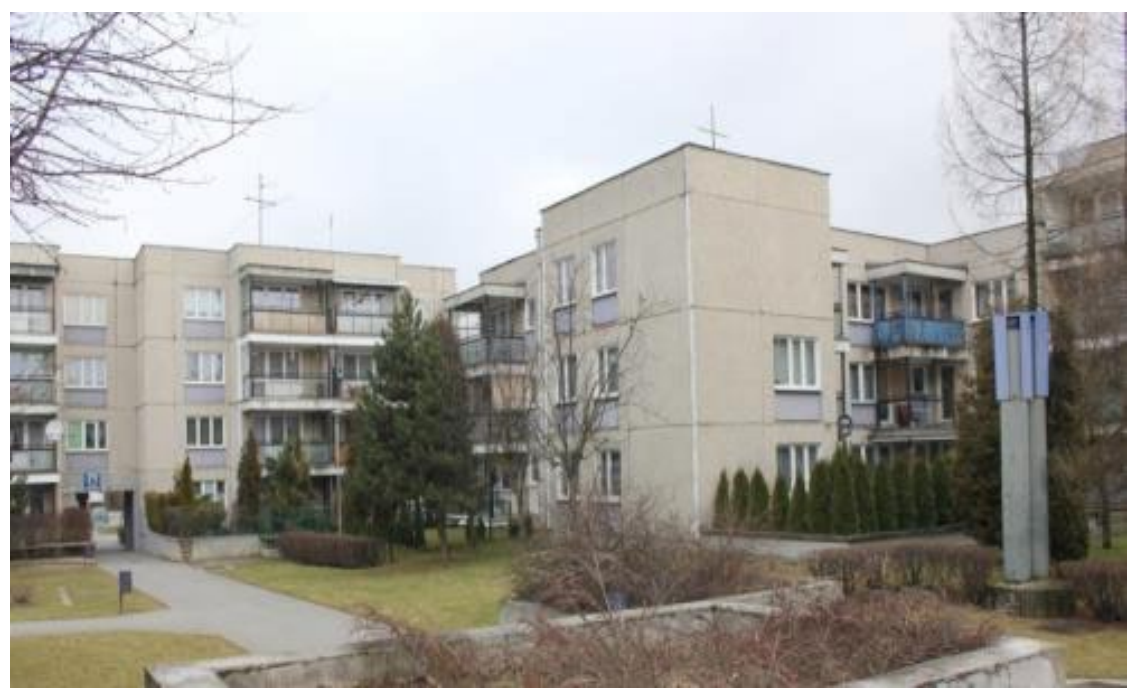

Ryc. 11. Przestrzeń międzybudynkowa. Autor fotografii: Michał Dmitruk

Public space between the buildings. Author of the photography: Michał Dmitruk

Godnym uwagi zabiegiem projektowym było również wprowadzenie do przestrzeni osiedla dwóch tak zwanych „budynków specjalnych". Były to obiekty w pełni przystosowane dla potrzeb osób niepełnosprawnych i starszych. Znajdowały się w nich mieszkania do których dostęp zapewniony został w sposób bezprogowy, od strony wewnętrznego patio. Dziedziniec tego niskiego, dwukondygnacyjnego obiektu był otwarty, przez co światło słoneczne wpadało do niego bezpośrednio a środek porastała roślinność i drzewa. Obecnie atrium jest przykryte przezroczystym zadaszeniem, ze względu na oszczędność energii grzewczej, a roślinność wymaga intensywnej pielęgnacji. (Ryc. 12. i 13.)
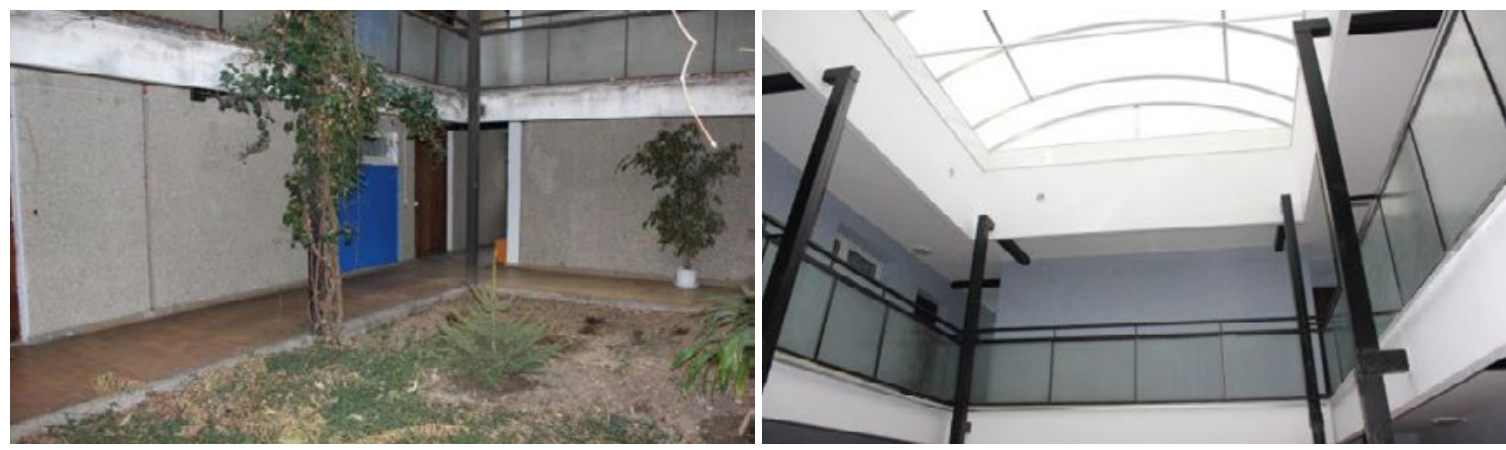

Ryc. 12. i 13. Patio wewnątrz budynku specjalnego (dla osób niepełnosprawnych). Autor fotografii: Michał Dmitruk Patio inside a special building (for disabled people). Author of the photography: Michał Dmitruk

Po ukończeniu kolejnych etapów, zwanych „zadaniami” uznano iż to techniczne określenie etapowania budowy nie jest nazwą odpowiednią dla poszczególnych części osiedla i nie będzie pomagać w identyfikowaniu się 
mieszkańców ze swoim miejscem zamieszkania. Wtedy właśnie wymyślono, żeby każdej z realizowanych kolonii nadać kolor przewodni, który będzie kojarzony z daną częścią osiedla. Tak powstały osiedla: Pomarańczowe, Niebieskie Zielone, Brązowe, Żółte i Fioletowe. Akcenty kolorystyczne, zaznaczone na blokach przeniesiono również na budynki towarzyszące funkcji mieszkalnej (świetlice, przedszkola itd.), obiekty małej architektury i wyposażenia technicznego. Tym sposobem ławki, kosze i wiaty na odpady, drzwi wejściowe do klatek schodowych, latarnie czy nawet tabliczki mieszkaniowe i wywiewy wentylacyjne zyskały kolor odpowiedni dla danego sektora. Nawet kładki łączące ze sobą części posiadają jeden kolor barierek poprowadzony do swojej połowy, a od drugiej strony kolor przynależny sąsiedniej części. Była to decyzja bardzo trafiona, gdyż zaczęto utożsamiać się z poszczególnymi kolorami, nawet wynosić odpady jedynie do pomalowanych na "swój" kolor wiat. W rozmowach po dziś dzień mieszkańcy identyfikują się poprzez zastosowany kolor przewodni na swoim osiedlu. Ta reguła projektowa jest skrupulatnie utrzymywana do dziś przy pracach modernizacyjnych, a nawet przy modyfikacjach mieszkańców wykonywanych na własną rękę - np. kraty w oknach parterowych i inne podobne elementy z własnej inicjatywy malowane są na odpowiedni kolor.
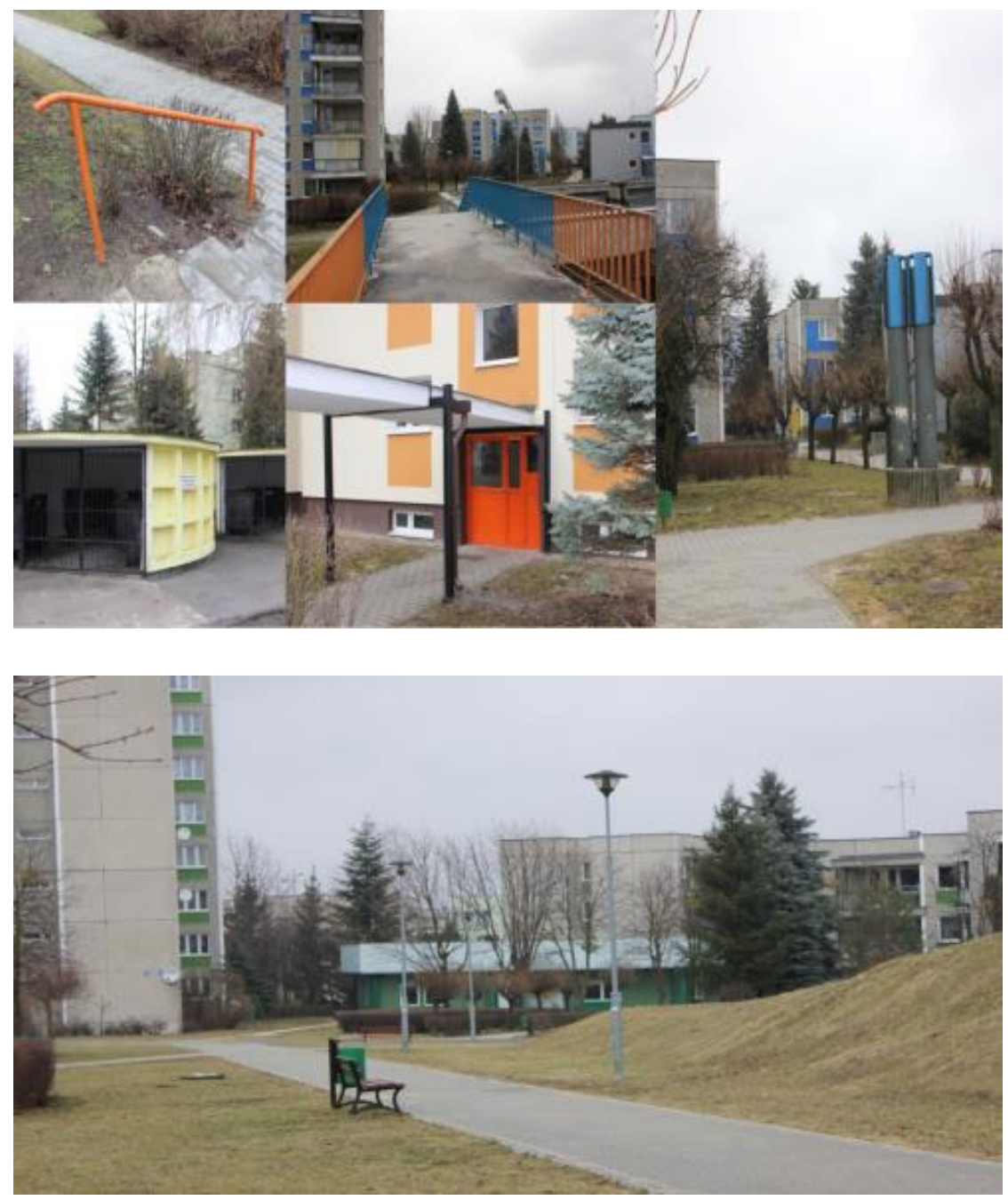

Ryc. 14. Kolorowe elementy wykończenia i małej architektury. Autor fotografii: Michał Dmitruk

Public space between the buildings. Author of the photography: Michał Dmitruk

Ryc. 15. Widok na fragment osiedla „zielonego”. Autor fotografii: Michał Dmitruk

View on the "green" part of the district. Author of the photography: Michał Dmitruk

Wykonując prace wykończeniowe na osiedlu, dużą uwagę skupiono na instalacji drobnych elementów ozdobnych i małej architektury. Wzdłuż ciągu spacerowego po środku osiedla ustawione są ławki i altany wypoczynkowe. W projekcie zieleni, opracowanym przez Euzebiusza Maja i wyróżnionym nagrodą Ministra Budownictwa założono pozostawienie dużej liczby drzew owocowych, rosnących na terenach ogrodów istniejących pierwotnie 
na omawianym obszarze ${ }^{16}$. Strefy zielone są gęsto obsadzone roślinnością, starannie zaprojektowaną w trzech planach - niska, średnia i wysoka - niekiedy na tyle gęsto, że trudno dostrzec rzeczywisty kształt budynku. Na osiedlu znajduje się wiele betonowych murków, donic i ogrodzeń, które wszystkie utrzymane są w spójnej, surowej i prostej estetyce.

Ważnym rozwiązaniem technicznym zastosowanym w "Nowym Mieście II" było prowadzenie wszelkich instalacji zasilających budynki wewnątrz podziemnych korytarzy, poprowadzonych pod całym obszarem przeznaczonym na osiedle. Rozwiązanie to, choć pierwotnie bardzo kosztowne, umotywowane było znaczną bliskością budynków względem siebie i brakiem możliwości operowania ciężkiego sprzętu. Obecnie okazuje się być bardzo efektywne, gdyż łatwo jest wykonać prace rewizyjne stanu instalacji, poruszając się tunelami, a w przypadku awarii łatwo o naprawę, bez konieczności używania ciężkiego sprzętu, i niszczenia nawierzchni strefy międzyblokowej. Wszelkie instalacje sanitarne i elektryczne rozprowadzone są tunelami do budynków mieszkalnych od centralnego budynku technicznego.

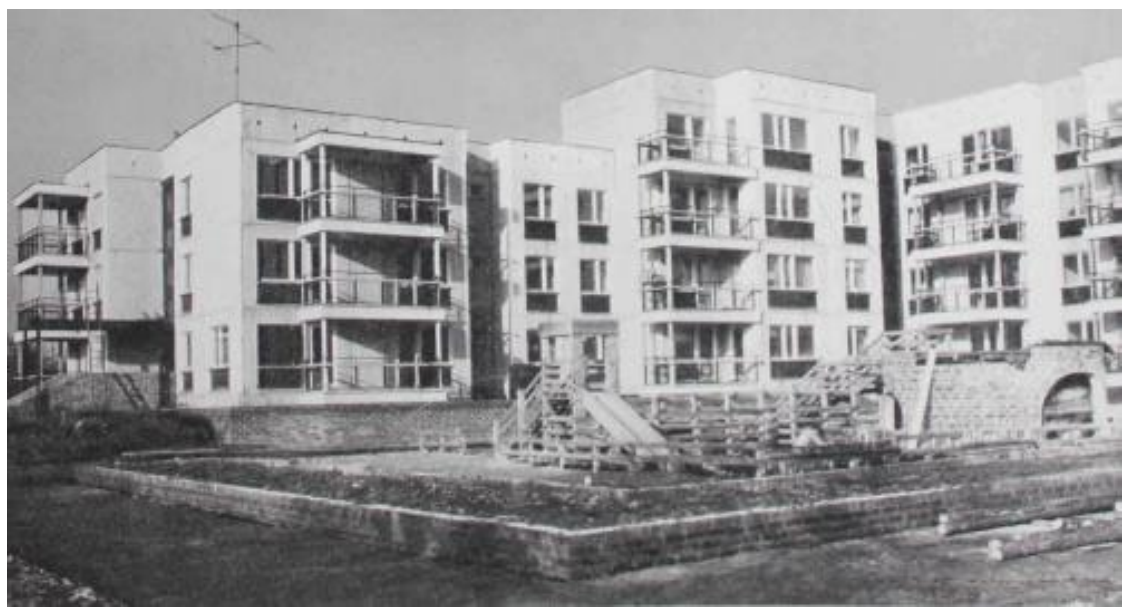

Ryc. 16. Widokjednego z budynków mieszkalnych - zdjęcie archiwalne. Źródło: Architektura. Czasopismo SARP

View of one of the multifamily buildings - years 80 's of the XX century. Source: Architektura. Czasopismo SARP

\section{Podjęte działania modernizacyjne}

Każdy wytwór techniczny człowieka, nie tylko budowlany, wraz z upływem czasu starzeje się i wymaga prac modernizacyjnych w celu utrzymania odpowiednich parametrów użytkowych. Aby działania poprawiające warunki bytowe mieszkańców przynosiły oczekiwane skutki, należy do nich podejść metodycznie i kompleksowo. W Zamościu, w sąsiedztwie historycznej architektury o znaczeniu światowym, bardzo trudno o pozyskanie środków finansowych na działania remontowe wielkopłytowych osiedli, gdyż zdają się być one obiektami drugiej kategorii. Z tego powodu administracja osiedla im. Jana Zamoyskiego zmuszona jest do podjęcia działań na rzecz zarówno zachęcenia mieszkańców do partycypacji finansowej, jak i do organizacji funduszy z programów pomocowych i inwestycyjnych. W pierwszym przypadku współpraca okazuje się być niezwykle trudna. Mieszkańcy początkowo nie są pozytywnie nastawieni do kwestii ponoszenia kosztów remontów, choćby w ich niewielkim procencie. Znacznie silniej do ich wyobraźni przemawia fakt iż comiesięczne opłaty podniosą się o kilkadziesiąt złotych, niż że na przestrzeni lat będzie to się wiązać ze znacznymi oszczędnościami. Zwykle po czasie przekonują się o pozytywnych skutkach zmian i wpływają na decyzje aprobujące zmiany wśród mieszkańców bloków sąsiednich, szczególne gdy rachunek za energię cieplną zaczyna wynosić ostatecznie o 100 zł

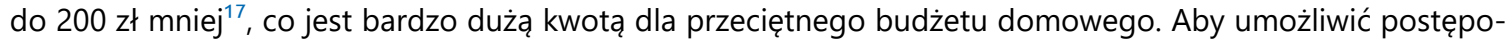
wanie procesów modernizacyjnych ustanowiono próg 60\%-70\% liczby mieszkańców, jako wystarczający do rozpoczęcia prac. Drugim źródłem finansowania modernizacji są kredyty z Funduszu Termomodernizacji i Re-

16 Na podstawie informacji uzyskanych od pana Euzebiusza Maja, 15.04.2016.

17 Dane na podstawie informacji uzyskanych od Spółdzielni Mieszkaniowej im. Jana Zamoyskiego w Zamościu ul. Wyszyńskiego 50 B, 22-400 Zamość. 
montu Banku Gospodarstwa Krajowego a także dofinansowania z Narodowego Funduszu Ochrony Środowiska i Gospodarki Wodnej i innych podobnych ${ }^{18}$. Tym sposobem zgromadzono w latach 2009-2010 8.499.700 zł na poczet prac termomodernizacyjnych, przy wsparciu NFOŚiGW ${ }^{19}$. Oczywiście o przyznaniu środków, kredytu czy dofinansowania decyduje wiele czynników - jednym z nich jest zwrot inwestycji na przestrzeni lat. Zgodnie z zasadami określonymi przez BGK, aby otrzymać dofinansowanie wynoszące do $20 \%$ kosztów inwestycji, powinna ona zwrócić się maksimum po 10 latach w kwocie oszczędzonej na energii grzewczej ${ }^{20}$. W tym celu przeprowadzono szereg badań i audytów energetycznych, ustalających kolejność prowadzenia prac i spełnienia wymogów formalnych. Badania przeprowadziła dr inż. Anna Życzyńska z Wydziału Budownictwa i Architektury Politechniki Lubelskiej. Pierwsze prace termomodernizacyjne polegały na wymianie stolarki okiennej i drzwiowej, a także usunięciu zbędnych okien piwnicznych i zaizolowaniu elementów powodujących powstawanie mostków termicznych. Co ważne, pilnowano również aby nowa stolarka posiadała jednakowe podziały okien, barwę i parametry wielkościowe, w celu przywrócenia jednolitości w wyglądzie elewacji ${ }^{21}$. Pozwolono również na zabudowę loggii w budynkach, ale jedynie według jednego zatwierdzonego projektu, w celu utrzymania jednolitości rozwiązań. Przypadki działania niezgodnego z wytycznymi projektowymi nakazano rozebrać. Wymiana okien i stolarki drzwiowej pociągnęła za sobą jednak dodatkowe komplikacje i wymusiła działania naprawcze, polegające na wprowadzeniu instalacji wspomagającej cyrkulację powietrza wewnątrz budynku. Pierwotnie instalacja wentylacji zakładała ruch powietrza poprzez nieszczelności w oknach - po wymianie okien nie powstawały już nieszczelności.

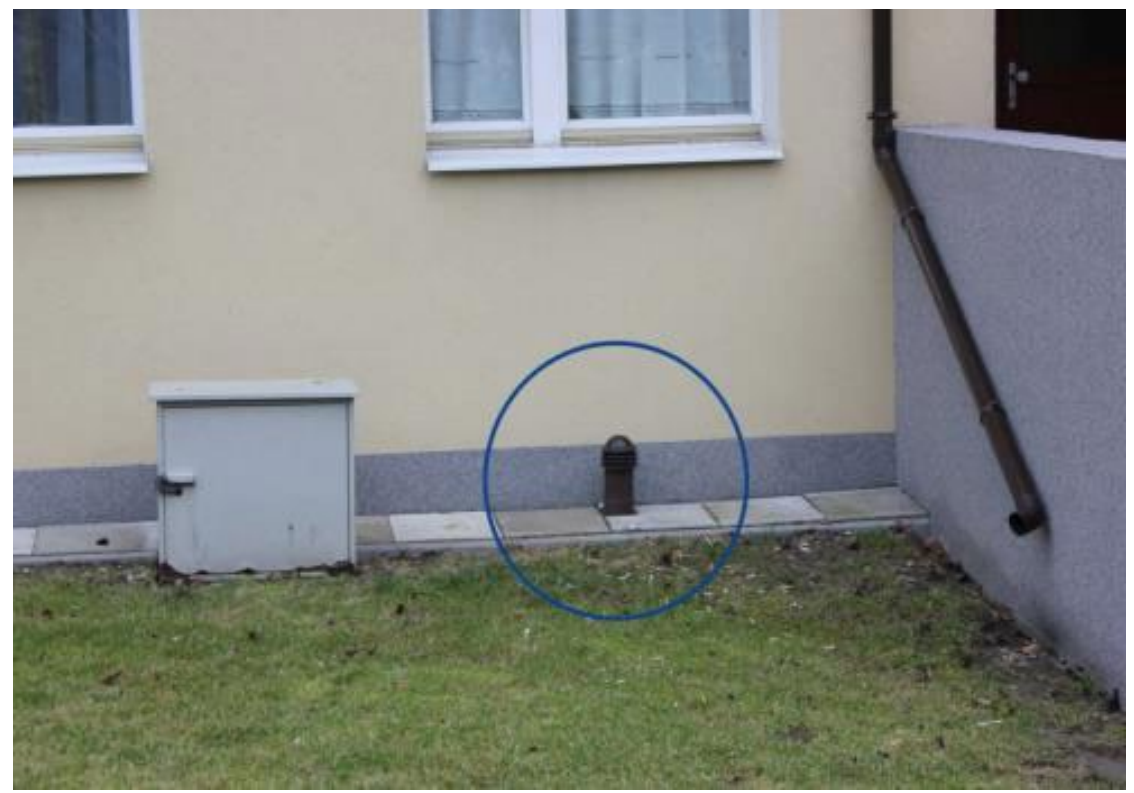

Ryc. 17. Jedno z urządzeń wspomagających cyrkulację powietrza wewnątrz budynku. Autor fotografii: Michał Dmitruk

One of the devices to aid air circulation inside the building. Author of the photography: Michał Dmitruk

Prace termomodernizacyjne prowadzone na osiedlu, ze względu na wyjątkowość architektury, stwarzają dodatkowe problemy natury ekonomicznej i inżynieryjnej. Przez ukształtowanie architektury w sposób zróżnicowany i wzbogacony o liczne loggie, wykusze, wnętrza i balkony, powierzchnia ścian zewnętrznych w relacji do powierzchni kondygnacji wynosi nawet $130 \%-140 \%$, a w stosunku do klasycznego budownictwa wielkopłytowego jest ona nawet większa dwukrotnie. Problemem jest również ułożenie i przenoszenie rusztowań, gdzie przy tak licznie występujących załamaniach ścian, ciasnych przejściach i wystających balkonach i murkach przy ogródkach nie sposób ustawić jednolitego, podłużnego pomostu roboczego. Mimo powyższych trudności, prace

18 M.in. z Eko-fundusz - fundacja powołana w 1992 przez Ministra Finansów w celu wspierania przedsięwzięć w ochronie środowiska.

19 Za: Tablica informacyjna projektu, znajdująca się na osiedlu.

20 Szczegóły programu na https://www.bgk.pl/samorzady/fundusze-i-programy/fundusz-termomodernizacji-i-remontow/i http://okieminzyniera. $\mathrm{pl} /$ premia-termomodernizacyjna-jak-ja-uzyskac/

21 Niejednokrotnie mieszkańcy wymieniali okna na własną rękę, stosując odmienną kolorystykę czy podziały. 
ociepleniowe prowadzone są zgodnie z harmonogramem na lata 2014-2020, zaczynając od budynków wymagających modernizacji w pierwszej kolejności ${ }^{22}$. Proces renowacji budynków przebiega w sposób zachowujący wartość architektoniczną osiedla. Kolory akcentujące architekturę poszczególnych kolonii są respektowane i stosowane również na elewacjach zmodernizowanych. Nasycenie barwne jest być może nieco zbyt duże (znacznie większe niż pierwotnie w szarych budynkach, jedynie z akcentem kolorystycznym), niemniej pozbawione zakłócającej odbiór estetyczny ornamentyki i prowadzone według założonego rytmu, nawiązującego do oryginalnie zastosowanych barw. Malowania przeprowadzone są w sposób uporządkowany i znacznie lepiej przemyślany niż często spotykane we współcześnie modernizowanych osiedlach wielkopłytowych. Wymieniane są również balustrady balkonowe, pierwotnie realizowane ze szkła zbrojonego - obecnie z blachy stalowej perforowanej, kwasoodpornej, dając efekt wizualny bardzo zbliżony estetycznie do oryginalnie stosowanych rozwiązań.

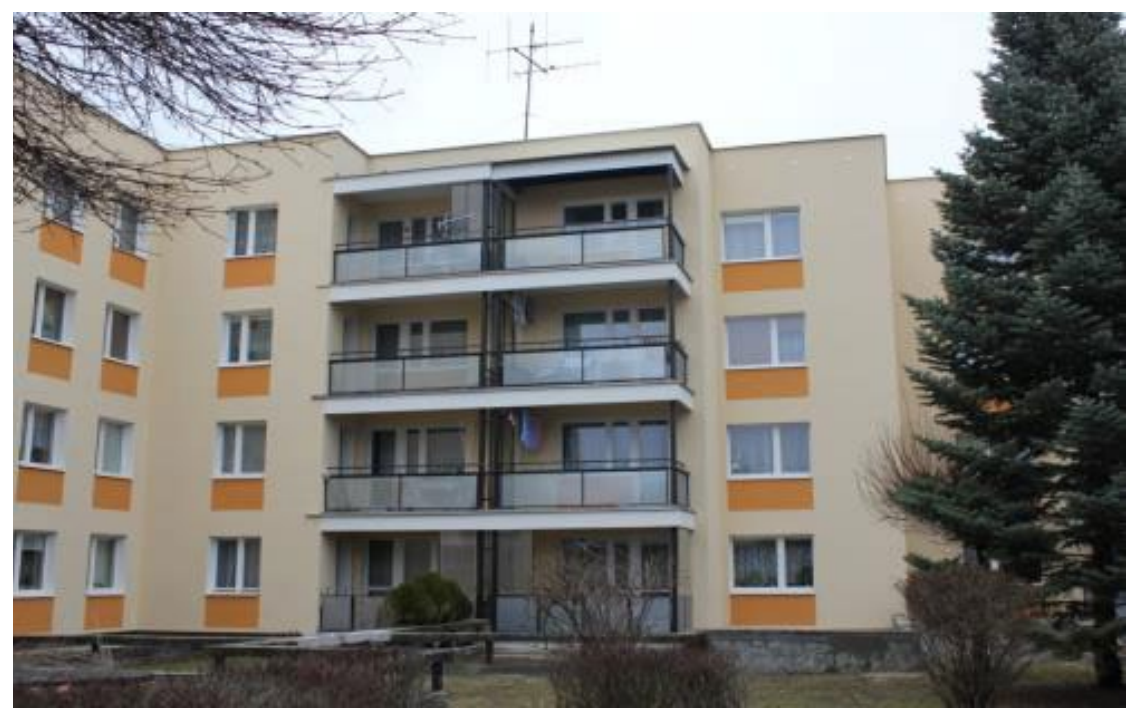

Ryc. 18. Budynek po modernizacji. Autor fotografii: Michał Dmitruk

Building after modernization. Author of the photography: Michał Dmitruk

Między innymi w ramach wspomnianego wcześniej funduszu „Eko-fundusz" zrealizowano na osiedlu im. Jana Zamoyskiego na szeroką skalę kompleksową instalację paneli solarnych, służących do podgrzewania wody. Według opinii przekazanej przez członka zarządu Spółdzielni Mieszkaniowej, jest to obecnie osiedle o największym zagęszczeniu paneli solarnych w Polsce. W związku ze sprawnym wydatkowaniem środków finansowych, koszt instalacji jedynie w $10 \%$ został pokryty z kieszeni mieszkańców. Łącznie z pracami montażowymi paneli, wykonano kompleksową przebudowę węzłów cieplnych i wymiennikowni, tak iż każdy budynek posiada własną odrębną sieć a mieszkańcy sami decydują kiedy należy rozpocząć sezon grzewczy a kiedy go zakończyć. Efektem przeprowadzonych prac jest spadek opłat naliczanych za wodę ciepłą z ok. $20 z^{23}$ za metr sześcienny do $7-9 z^{24}$.

Istotnym novum w procesie modernizacji osiedla jest obfitość różnego rodzaju murków, donic, koryt i ogrodzeń wykonanych oryginalnie z betonu. Poprzez zastosowanie jako dodatek do betonu kruszywa węglanowego otrzymano znacznie większą twardość materiału, natomiast jak się okazało w późniejszym czasie również znaczeni większą nasiąkliwość, co z kolei wpływało na przyspieszone niszczenie materiału poprzez warunki atmosferyczne. Jako, że ilość elementów betonowych na osiedlu uniemożliwia bieżące naprawy, cześć z nich jest usuwana, bądź zastępowana nasypem ziemnym obsadzanym roślinnością.

Celem Spółdzielni mieszkaniowej na lata 2016-17 jest również likwidacja barier architektonicznych, pod kątem korzystania z przestrzeni przez osoby niepełnosprawne. Szachownicowy układ alejek i chodników, a także

22 W trakcie prowadzenia budowy osiedla, polskie normatywy dotyczące izolacyjności cieplnej przegród zewnętrznych zmieniały się kilkukrotnie - stąd inna grubość warstwy izolacyjnej wewnątrz płyty i inne wartości utraty ciepła w poszczególnych budynkach.

23 Przeciętna stawka obowiązująca w SM w Zamościu

24 Na podstawie informacji uzyskanych od Spółdzielni Mieszkaniowej im. Jana Zamoyskiego w Zamościu ul. Wyszyńskiego 50 B, 22-400 Zamość. 
liczne przejścia w formie prześwitów generowały wiele różnic w poziomie terenu, pierwotnie rozwiązywanych poprzez zastosowanie kładek i schodów.

Obecnie schody mają być stopniowo zastępowane pochylniami i rampami w celu ułatwienia poruszania się po osiedlu matkom z wózkami dziecięcymi i osobom starszym. Zabieg ten ma na celu humanizację przestrzeni wspólnej i stworzenie odpowiednich warunków do korzystania z niej dla wszystkich mieszkańców.

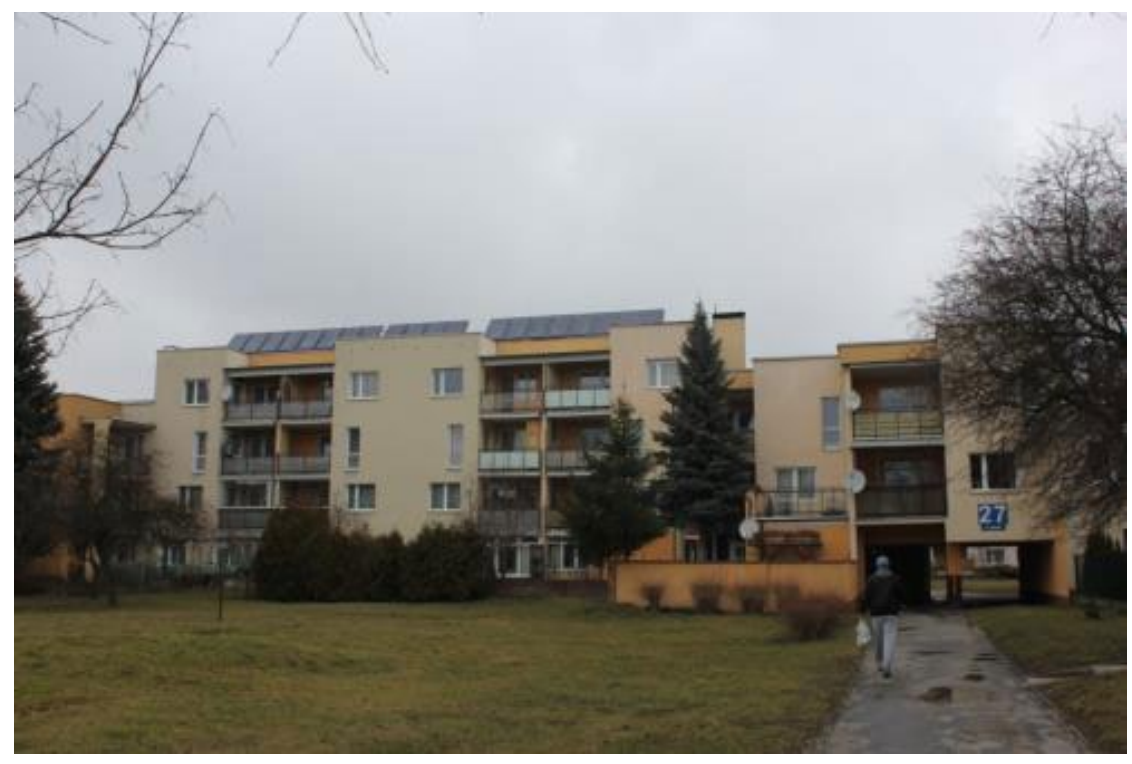

Ryc. 19. Zainstalowane na dachu budynku panele solarne. Autor fotografii: Michał Dmitruk

Solar panels installed on the roof of the buildings. Author of the photography: Michał Dmitruk

\section{Podsumowanie}

Pośród licznie obecnych w Polsce osiedli z wielkowymiarowych elementów prefabrykowanych znajdują się takie, którym warto poświęcić dodatkową uwagę. Takim przykładem jest niewątpliwie jest osiedle im. Jana Zamoyskiego w Zamościu. Zaprojektowane zostało w sposób przemyślany i kompleksowy, z szacunkiem do niezwykle istotnego, historycznego kontekstu miejsca. Decyzje projektowe zarówno w zakresie urbanistyki i architektury starają się nadać przestrzeni ludzki wymiar i maksymalnie zhumanizować budownictwo kojarzone często z przedmiotowym i pozbawiającym indywidualności traktowaniem mieszkańców i ich potrzeb. Eksperymentalne technologie i rozwiązania wykraczające poza standardy przyjęte za normę w latach 80-tch XX wieku, okazały się przełomowymi i w obecnych czasach bardzo pożądanymi.

Obecnie osiedle wymaga wielu działań modernizacyjnych i naprawczych. Wiele z nich w sposób umiejętny i konsekwentny realizowane jest przez Spółdzielnię Mieszkaniową im. Jana Zamoyskiego w Zamościu. Istotnym jest, aby w procesie zmian rewitalizacyjnych nie zagubić niezwykłego charakteru osiedla i tych jego walorów, które stanowią o jego wyjątkowości.

\section{Piśmiennictwo}

[1] Gliński A. [red.], 1983. Architektura. Czasopismo Stowarzyszenia Architektów Polskich, Arkady,

[2] Kędziora A., 2000. Encyklopedia miasta Zamościa, Towarzystwo Opieki nad Zabytkami, Chełm.

[3] Kowalczyk J., 1995 Zamość. Przewodnik, Zamojski Ośrodek Informacji Turystycznej, Zamość.

[4] Wojtkun G., 2011, Wielka ptyta na styku żelaznej kurtyny, [w] Przestrzeń i Forma nr 15

[5] Zieleniewski S., Nowak Z.,1975. Tło i charakterystyka ogólna programu rządowego PR-5 „Kompleksowy rozwój budownictwa mieszkaniowego", Akademia Ekonomiczna. Instytut Organizacji, Zarządzania i Ekonomiki Przemysłu Budowlanego. Zakład Ekonomiki Budownictwa i Inwestycji, Kraków. 
[6] Żygawski J., 2015. Niezrealizowane projekty śródmieścia Zamościa w XIX i XX wieku na podstawie archiwalnych opracowań kartograficznych i planistycznych, TEKA Komisji Urbanistyki i Architektury PAN oddział w Krakowie, tom XLIII, Kraków.

[7] Akty prawne i źródła internetowe: Dz. U. z 1975 r. Nr 16, poz. 91

[8] https://www.bgk.pl/samorzady/fundusze-i-programy/fundusz-termomodernizacji-iremontow/

[9] http://okieminzyniera.pl/premia-termomodernizacyjna-jak-ja-uzyskac/

[10] https://pl.wikipedia.org/wiki/EkoFundusz

\section{Jan Zamoyski`s housing district in Zamość - implementation of PR-5 programme and modernisation efforts}

Abstract: Among the many prefabricated housing blocks built in Poland over the years from the 70s to the 90 s of the twentieth century, Jan Zamoyski’s Housing District in Zamość deserves a special attention. Created as an implementation of the governmental PR-5 project has unique urban - architectural values and avant-garde technical solutions, unprecedented in any of the previously built large panel settlements in Poland. Currently, community administration office makes every effort to modernize, revitalize and maintain the modern utility standards of the buildings.

Key words: great panel, prefabrication, modernization, revitalization, humanization 